\title{
An analysis of proportional reasoning ability of junior high school students
}

\author{
Fitria Mardika ${ }^{1, \text { a, }}$, Ali Mahmudi ${ }^{2, \text { b }}$ \\ ${ }^{1}$ Department of Mathematics Education, UIN Imam Bonjol Padang \\ Jl. Prof Mahmud Yunus, Padang, Sumatera Barat, 25171, Indonesia \\ ${ }^{2}$ Department of Mathematics Education, Universitas Negeri Yogyakarta \\ Jl. Colombo No. 1, Karangmalang, Yogyakarta 55821, Indonesia \\ E-mail: ${ }^{a}$ fitriamardika@uinib.ac.id, b alimahmudi@uny.ac.id \\ * Corresponding Author
}

\begin{tabular}{|c|c|}
\hline ARTICLE INFO & ABSTRACT \\
\hline \multirow{2}{*}{$\begin{array}{l}\text { Article history } \\
\text { Received: } 24 \text { July } 2017 \\
\text { Revised: } 19 \text { October } 2020 \\
\text { Accepted: } 19 \text { May } 2021 \\
\text { Keywords } \\
\text { proportional reasoning, } \\
\text { proportion problem, direct } \\
\text { proportion, inverse } \\
\text { proportion, mathematics } \\
\text { learning }\end{array}$} & $\begin{array}{l}\text { This study aims to describe proportional reasoning skills and students' difficul- } \\
\text { ties in solving proportional reasoning problems. The population of this research } \\
\text { was } 3480 \text { seventh grade students of state junior high schools in the Yogyakarta } \\
\text { region. The samples were } 158 \text { students chosen using proportionate stratified } \\
\text { random sampling that represent four categories of school (very high, high, me- }\end{array}$ \\
\hline & $\begin{array}{l}\text { dium, low) based on the average scores of the national examination in mathe- } \\
\text { matics in } 2016 \text {. Data were collected through essay tests and interviews. Data } \\
\text { were analyzed quantitatively and qualitatively. The result showed that the stu- } \\
\text { dents in very high and high category schools had moderate proportional rea- } \\
\text { soning ability. Students in medium and low category schools had low propor- } \\
\text { tional reasoning ability. Students' difficulties in solving proportional reasoning }\end{array}$ \\
\hline \multirow{2}{*}{ 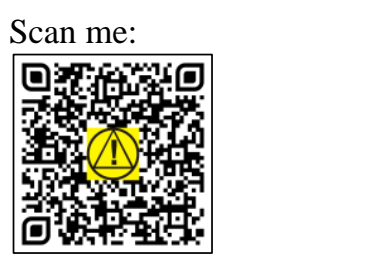 } & $\begin{array}{l}\text { problems vary based on the type of the problem, such as the difficulty in finding } \\
\text { the multiplicative relationship contained in the problem, the difficulty in under- } \\
\text { standing the value of inverse proportion, and the difficulty in explaining the } \\
\text { obtained solution of the problems. }\end{array}$ \\
\hline & This is an open access article under the CC-BY-SA license. \\
\hline
\end{tabular}

How to Cite: Mardika, F., \& Mahmudi, A. (2021). An analysis of proportional reasoning ability of junior high school students. Jurnal Riset Pendidikan Matematika, 8(1), 22-32. https://doi.org/10.21831/jrpm.v8i1.14995

\section{INTRODUCTION}

Problems about proportion can be found in daily life. When someone made the cooking recipe, they thought about the best composition to make the food delicious. And while they go shopping in the store and spotted a different type of discount for certain goods, they will think proportional without them conscious about the discount or the way they will purchase beneficially. NCTM (2000, p. 212) stated that proportion is integrated into many aspects of high school mathematics, such as ratio, percentage, scale, linear equation, and many others. Most mathematicians define proportion as two same ratios (Langrall \& Swafford, 2000, p. 255). Proportion can also define as a more general concept that is specifically reflected on fraction, percentage, decimal topics. Considering the urgency of proportion in real life, the student needs to master the proportion concept.

In Indonesia, proportions have already been taught since elementary school through fractions, ratios, the introduction of patterns, and the shapes of geometry materials. Proportion concept found on grade VII while students learn about ratio concept (Ministry of Education and Culture, 2016). Proportion concepts are also required to understand the transformation concept (dilation, translation, reflection, and rotation). Students need to know that if an object is being stretched or shrunk, its reflection will change like the measurement itself. In addition, students need the proportion concept when encountering the more complex mathematics concept such as algebra in senior high school.

It is not surprising that students can solve proportion problems since the concept is taught from an early age. Besides solving the proportion problem, students are also foreseen to have reasoning abilities connected to the proportion problem. The reasoning is one of the learning objectives and the core 


\section{Jurnal Riset Pendidikan Matematika, 8 (1), 2021 - 23}

Fitria Mardika, Ali Mahmudi

competencies in mathematics (Ministry of Education and Culture, 2016). Reasoning in mathematics learning is considered essential because it is the basis for structuring students' mathematical understandding (Howe et al., 2011).

Proportional reasoning is the skills to detect, express, analyze, explain, and give proof to underline the relation of proportion (Lamon, 2012). McIntosh (2013, p. 7) states that proportional reasoning is not just the skill to make a proportional problem or apply cross multiplication to find the missing number from any mathematics problem. Proportional reasoning is preferable to using number sense application rather than formal and procedural solving the proportional problem. Van de Walle (2007, p. 353) said that it is difficult to define proportional reasoning in one or two simple sentences. Proportional reasoning is a skill everyone could master through the long-time process of development. Proportional reasoning involves thinking about relationships or make ratios from the quantity or value. Lobato and Ellis (2010, p. 63) said proportional reasoning is about how we think relatively rather than absolute thinking about relation or quantity and the change from additive reasoning to multiplicative reasoning. Steinthorsdottir (2005, p. 225) explains that people with additive reasoning use quantity or number from a ratio to solve problems; meanwhile, multiplicative reasoning uses multiplicative relation from two things or elements from a ratio to solve the problem. Multiplicative relation is one of the characteristics of a proportional problem. As Lesh et al (Modestou \& Gagatsis, 2010, pp. 38-39) said, every proportional relation includes the same pattern of operation, and also the components have the multiplicative relation one another.

Based on the analysis, it would be a matter when students' proportional reasoning skills are not as good as their skills to solve the proportion problem. According to Tjoe and Torre (2013, p. 18), students with better problem-solving skills would understand that the cross-multiplication method can solve proportion problems. However, the ability of students to use these methods well does not guarantee that students' ability to think proportionally is also good. By means, they only understood procedural problem-solving.

Age and education level do not guarantee that someone has good proportional reasoning ability. In line with Lamon $(2012$, p. 3), more than $90 \%$ of adults cannot reason proportionally. That means, it is not only elementary or high school students that it is possible not to understand the proportional relationship of a problem, but even adults who in their daily life encounter many elements of proportion do not understand the proportions throughout them. The learning process also performs an active role in the development of students' proportional reasoning abilities.

Proportional reasoning is continuous progress. Therefore, teachers have an important role in the development of students' proportion reasoning abilities. First, the teacher needs to know the student's mindset related to proportional reasoning to apply the right teaching strategy. In Indonesia, this has not been fully implemented. This reality is in line with Sumarto (2013, p. 2), which states that some teachers in Indonesia teach the cross-multiplication method for proportion material that is integrated with fraction material. Although students may solve the problem of proportions with this method, it is possible that students only memorize the completion procedure using the cross-multiplication method so that the students' proportional reasoning ability does not develop.

Apprehending and planning the right teaching strategy is indeed important for teachers to implement, but creating a data baseline on students' proportional reasoning abilities and looking for the students' difficulties in solving proportional and non-proportional problems is the key or initial step for teachers to help them develop proportional reasoning (Hilton et al., 2016, p. 3). That shows the importance of research to help teachers describe students' proportional reasoning abilities. Carney et al. (2015) stated that research is needed to find out how the progress and development of students in proportional reasoning. Schools and teachers need more resources to foster student proportional reasoning.

Research on students' proportional reasoning abilities has been done a lot. Dooley (2006, p. 6) said that in the last 20 years, there had been several studies on strategies used by students in solving proportional reasoning problems (e.g., Ben-Chaim et al., 2012; Carney et al., 2015; Lamon, 1993; Langrall \& Swafford, 2000; Prayitno et al., 2019; Sumarto, 2013). Several previous studies have exhibited theories about proportional reasoning problem-solving strategies at the elementary, junior high, and senior high school levels. From some of these studies, however, there are still few studies that discuss students' proportional reasoning abilities based on student learning achievement.

Students' proportional reasoning abilities differ, as mentioned earlier. Meanwhile, it remarkable that the learning achievement of students in Indonesia also varies. Those variations lead to differences in the reasoning process in solving the problems. Heterogeneous student learning achievement raises 
various assumptions regarding the student's proportional reasoning ability. Students with good problemsolving about proportion and have excellent grades will not have good proportion reasoning inevitably. That is something researchers will look up to. How does a reflection of student achievement on their proportional reasoning ability are crucial to research to add to teachers' insight as facilitators for students' proportional reasoning abilities development?

In this study, proportional reasoning is the student's ability to understand the proportional relationship of a quantity or value that can be seen from the ability to express, analyze, and explain this proportional relationship. The indicator of proportional reasoning in this research is explained as follows. The first one is to express a proportional relationship into a mathematical model. NCTM (2000, p. 280) explains that junior high school students solve problems by creating and using a problem representation to organize and record their mathematical thinking about the proportional problems. For example, they solve these by making object representations in images or scales for the problems related to geometric material. Second, students can create a visualization that brings visual information and numbers to describe the relationship between quantities. Finally, students can use standard or non-standard representations for the more complex problem that resembles another problem.

Second, analyzing a proportional relationship. As previously explained, one of the important components' students have in understanding proportional relationships is understanding the concept of units. That is associated with students' understanding of numbers closely. Students struggle with numbers, fractions, and ratios in solving problems regarding proportions. NCTM (2000, p. 216) suggests that junior high school students should see the fractions as a measure, quantity, or location where the number is placed and understand the relationship between the components of the fraction. The analysis of a proportional relationship is related to the multiplicative reasoning ability of students. To reach this reasoning, students must have a solid number concept. Ben-Chaim et al. (2012, p. 53) explain that students get the incorrect answer in solving the problem of the proportion from using additive reasoning or improper use of multiplicative reasoning. In contrast, students' correct answers can be obtained when students use multiplicative reasoning that is correct and used well. Appropriate multiplicative reasoning identifies an intuitive awareness of the ratio or proportion so that the variables in the proportion can be placed correctly. Students can also obtain the correct required answers through the appropriate settlement procedures both quantitatively and qualitatively.

Third, explain the answers given regarding a proportional relationship. The ability of students to solve proportional problems does not guarantee their high proportional reasoning ability. Some students can solve the problem of proportion procedurally without thoroughly understanding the concept of proportion. Teachers can improve students' communication skills as one of the ways. NCTM (2000, p. 271) explains that the teacher plays a role in creating a classroom atmosphere that permits students to express their opinions when solving a problem. Students with good reasoning can solve a problem with the right strategy, explain the problem, and find a solution. Students must be able to ensure that the answers given are correct.

The difference in students' proportional reasoning ability can be reflected in the different strategies they use to solve a problem. The study of Langrall and Swafford (2000) described the characteristics of the strategies in solving proportional reasoning problems that later grouped into levels of proportional reasoning ability. Guided by the student proportional reasoning level described by Langrall and Swafford (2000), this study will report the analysis of students' proportional reasoning ability based on student learning achievement refers to the average score of the national examination in 2016 to acquire new knowledge about the proportional reasoning ability based on the learning achievement of junior high school students. Based on the background of the problem and the theoretical study discussed, the purpose of this study is to describe the level of students' proportional reasoning ability and identify the difficulties encountered by junior high school students in solving proportional reasoning problems.

\section{METHOD}

This is a survey research with quantitative and qualitative approaches used concurrently where quantitative and qualitative data are collected gradually but interpreted simultaneously (Creswell \& Plano-Clark, 2011, p. 83). The population of this research is seventh grade students of 16 public junior high schools in Yogyakarta City, Indonesia, with a total number of 3,480 students. Each school was sorted based on the Mathematics National Examination average score in 2016 into four categories (very 
high, high, moderate, low). The criteria for grouping schools based on the scores are presented in Table 1 .

Table 1. School criteria based on national examination scores in 2016

\begin{tabular}{ll}
\hline Mean $(M)$ & Criteria \\
\hline$M>85$ & Very high \\
$70<M \leq 85$ & High \\
$55<M \leq 70$ & Medium \\
$M \leq 55$ & Low \\
\hline
\end{tabular}

Four schools were in the very high category, seven schools in the high category, three schools in the medium category, and two schools in the low category. Furthermore, it was determined the number of schools that will represent each school group. The minimum sample size for the very high, medium, and low school groups was one school, respectively, and for the high group, two schools were taken. The sample selection was carried out using the proportionate stratified random sampling technique. The study sample consisted of 158 students (31 students from very high schools, 64 students from high schools, 32 students from medium schools, and 31 students from low schools).

The data collection instrument was in the form of a proportional reasoning ability test which consisted of three description questions representing the types of proportion problems, namely direct proportion, inverse proportion, and proportion problems. Data collection also used semi-structured interview guidelines, meaning that the researcher prepares general interview questions to become a reference in carrying out the interview process. Each type of problem in the test was then assessed based on the indicator of proportional reasoning ability. The indicators used in this study are based on Lamon (2012, p. 4), namely, students can: 1) express a proportional relationship into a mathematical model; 2) analyzing a proportional relationship; 3) explain the answers given regarding a proportional relationship. Two mathematics education lecturers have validated the test instruments and interview guides who have taken doctoral programs.

After students were given a written test, the test results were collected to describe the student's level of proportional reasoning ability. The criteria for students' proportional reasoning ability in each school category refer to the criteria by Azwar (2015, p. 132), as presented in Table 2. The students were then interviewed to confirm and enrich the data about their ability of proportional reasoning. Previously, the sample of students was determined for the interview stage. The interview sample was three students taken from each school which was the research sample. The selected students are those with different proportional reasoning abilities. After selecting student representatives, interviews were conducted with students at the agreed time with the mathematics teacher's consent.

The interview results were analyzed based on Creswell and Plano-Clark (2011) by confirming or reaffirming students' written test answers and reflecting their proportional reasoning ability. For example, students were given questions about the direct proportion "Given that the price of 20 notebooks is 46,000 IDR. How much it cost for 12 notebooks?". One of the assessment indicators is the student's ability to write a mathematical model for the problem correctly. The interview process is useful to confirm whether the answers given by students in writing are correct and reflect the ability of proportional reasoning. Students were asked about the meaning of the equation or mathematical model they wrote with the given problem.

Table 2. Student proportional reasoning ability criteria

\begin{tabular}{lll}
\hline Description & Score interval & Criteria \\
\hline Criteria formula & $X>M_{i}+S D_{i}$ & High \\
& $M_{i}-S D_{i}<X \leq M_{i}+S D_{i}$ & Moderate \\
& $X \leq M_{i}-S D_{i}$ & Low \\
\hline General criteria & $X>18$ & High \\
& $9<X \leq 18$ & Moderate \\
& $X \leq 9$ & Low \\
\hline Criteria for each question & $X>6$ & High \\
& $3<X \leq 6$ & Moderate \\
& $X \leq 3$ & Low \\
\hline
\end{tabular}




\section{RESULTS AND DISCUSSION}

\section{Results}

\section{General Student Proportional Reasoning}

Students' answers to the proportional reasoning ability test are grouped by school category and then calculated the total score obtained by each school category and the school's average score. The maximum score that each student for each question can obtain is 9. The maximum score for the proportional reasoning ability test is 27 . After the average score is obtained, then the criteria for the student's proportional reasoning ability are determined. In general, students' proportional reasoning ability for all questions based on school categories can be seen in Table 3.

Table 3. Students' general proportional reasoning skills

\begin{tabular}{lccl}
\hline School category & Total score & Mean score & Criteria \\
\hline Very high & 494 & 15.94 & Moderate \\
High & 724 & 11.31 & Moderate \\
Medium & 216 & 6.75 & Low \\
Low & 153 & 4.94 & Low \\
\hline
\end{tabular}

Table 3 shows that the school category is directly proportional to the students' general proportionnal reasoning ability. The better the school category, the higher the students' average score of proportional reasoning ability. However, based on the criteria for proportional reasoning ability, it was found that school students' abilities with very high and high categories were still classified as moderate. In contrast, students in medium and low categories were classified as having low proportional reasoning abilities. Based on these results, there is no difference in proportional reasoning between students in very high category schools and high category school students between students in the medium and low category schools.

In addition to the average score for all the questions, the researcher also described the average score of each item for each school category. This aims to see the tendency of students' abilities in solving each given question. The average score for each question can be seen in Table 4 .

Table 4. Students' proportional reasoning ability for each question

\begin{tabular}{llll}
\hline School Category & Question 1 & Question 2 & Question 3 \\
\hline Very High & 5,55 (Moderate) & 5,23 (Moderate) & 5,16 (Low) \\
High & 4,36 (Moderate) & 4,05 (Moderate) & 2,91 (Low) \\
Medium & 2,50 (Low) & 1,63 (Low) & 2,63 (Low) \\
Low & 2,58 (Low) & 1,19 (Low) & 1,16 (Low) \\
\hline
\end{tabular}

Table 4 shows that students in very high and high categories have the ability of proportional reasoning who are solving comparative problems of value (Problem 1). Meanwhile, students in medium and low categories of schools have a low proportional reasoning ability in solving problem 1 . Although not significant, it can be seen that the average school score in the medium category is lower than the average score for the low category school.

Table 4 also shows that student learning achievement is directly proportional to students' proportional reasoning in solving inverse proportion problem (Problem 2) and proportion problems (Problem 3 ). This can also be seen from the proportional reasoning ability criteria for question 3, where only students at very high schools are classified as having moderate abilities. Meanwhile, high, medium, and low school students have low proportional reasoning ability.

Based on this description, the conclusion is that there are no students who had high proportional reasoning ability. Therefore, it is necessary to look at the causes or difficulties they had in solving each given question. Thus, it is to know the tendency of students' abilities to solve each problem and look for the difficulties or the factors that affect the students' proportional reasoning ability.

\section{Student Difficulties in Solving Proportional Reasoning Problems}

After describing the ability of proportional reasoning in general, the next is to discuss the difficulties encountered by students in solving the problem of proportions. After teachers gave the proportional 
reasoning ability test to the students, their answers were organized to determine what mathematical models the students tended to use to solve comparative problems of value (Problem 1). After grouping the students' answers, several solutions by students were found, as in Figure 1.

\begin{tabular}{|c|c|}
\hline $\begin{array}{l}\text { Diketahui harga } 20 \text { buku tulis ndalah Rp. } 46.000,00 \text {. Berapakah harga } 12 \\
\text { buku tulis tersebut? }\end{array}$ & $\begin{array}{l}\text { Diketahui harga } 20 \text { buku tulis adalah Rp.46.000,00. Berapakah harga } 12 \\
\text { buku tulis tersebut? }\end{array}$ \\
\hline $\begin{array}{l}\text { Diketahui } 20 \longrightarrow R p 96.000,00 \\
\text { Ditangakan. harga } 12 \text { buku tulis? } \\
\text { Jawob. } x \cdot \frac{x^{6}}{29} \times 46.000 \text { : } 27.600 \\
\text { Jadi haga } 12 \text { buku tutis adaloh Rp27.600,00 }\end{array}$ & 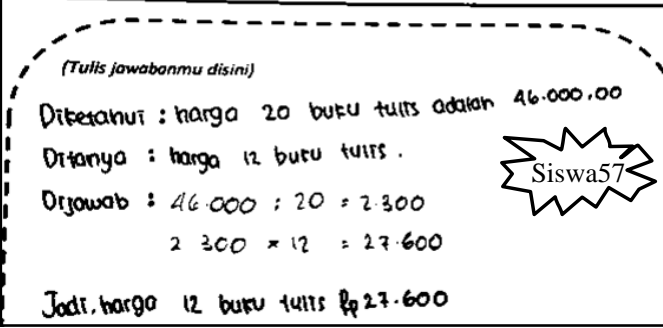 \\
\hline $\begin{array}{l}\text { Translations: } \\
\text { Given that the price of } 20 \text { notebooks is } 46,000 \\
\text { IDR. How much is the price for } 12 \text { notebooks? } \\
\text { Student } 21 \\
\text { Given: } 20 \rightarrow 46,000 \text { IDR } \\
\quad 12 \rightarrow x \\
\text { Asked: the price of } 12 \text { notebooks } \\
\text { Answer: } x=\frac{12}{20} \times 46,000=27,600 \\
\text { So, the price of } 12 \text { notebooks is } 27,600 \text { IDR }\end{array}$ & $\begin{array}{l}\text { Given that the price of } 20 \text { notebooks is } 46,000 \\
\text { IDR. How much is the price for } 12 \text { notebooks? } \\
\text { Student } 57 \\
\text { Given: the price of } 20 \text { notebooks is } 46,000 \text { IDR } \\
\text { Asked: the price of } 12 \text { notebooks } \\
\text { Answer: } 46,000: 20=2,300 \\
2,300 \times 12=27,600 \\
\text { So, the price of } 12 \text { notebooks is } 27,600 \text { IDR }\end{array}$ \\
\hline
\end{tabular}

Figure 1. Examples of student answer to question 1

Figure 1 shows the mathematical models used by the students in answering question 1 . From the total sample of the study, there were two types of solutions used by the students. First, students try to use a formal mathematical model for direct proportion done by Student 21. This mathematical model is in line with the formal form of direct proportion by Ben-Chaim et al. (2012, p. 33) that the direct proportion consists of four variables where one of the variables has an unknown value. Second, students use the unit concept to construct a mathematical model of the direct proportion problem as Student 57 did.

The results of the interviews with students indicated that some of them could write a mathematical model of the direct proportion appropriately. However, when teachers asked about the meaning of the equation or the mathematical model they wrote, students could not explain it well. For example, students knew that the problem in question 1 is a direct proportion problem, but students cannot explain the real meaning of direct proportion. Consequently, many students use the formula or the formula from the direct proportion incorrectly.

Ben-Chaim et al. (2012, p. 33) proposed that direct proportion points to the change in the value of one quantity directly corresponding to another quantity. Based on problem 1, the changes in the number of books will be directly proportional to the changes in the book's price. That means that the more books purchased, the more money spent on buying these books. From the 15 students interviewed in this study, students who understand the concept of the unit can explain the mathematical model they used well. Meanwhile, students who think qualitatively can write the appropriate mathematical model but cannot verbally explain it.

Based on indicator two about the answers and students' ability to analyze the proportional relationship asked in the questions, even though students can correctly answer direct proportion, many students still unable to analyze the relationship between the price of 20 notebooks and 12 notebooks. Students gave several types of answers on indicator 2: (a) students cannot write down the relationship between the price of 20 notebooks and 12 notebooks. Meaning that the student did not give an answer or answered nor it was not relevant at all; (b) write down the relationship between the price of 20 notebooks and 12 notebooks qualitatively; (c) write down the relationship between the price of 20 notebooks and 12 notebooks in an additive way. Students in this category understand that 12 notebooks are cheaper than 20 notebooks. However, the price difference is the gap between the two prices; (d) some students use the unit concept correctly. Students in this category understand that with every change in the number of books, the book price will also change with the same value. 
Indicator 3 for question 1 demands students to write another solution for question 1 . That aims to see the extent of students' ability to solve direct proportion problems and find unique and varied alternative answers. Unfortunately, the other methods given by the students are still the same as in Figure 1. Students who initially solve the direct proportion problem using the formal mathematical model of the direct proportion later write down the solution using the unit concept in the next section. There were three categories of students in solving direct proportion problems. First, the students who cannot solve the problem properly. Second, students who can only solve problems using one solution strategy (formal or unit). Third, students who can solve these with two solving strategies (using a formal mathematical model and using the unit concept).

For question 2, there are several ways of solving problems shown by students, as in Figure 2. From the total students as the sample, there are two types of solutions used. First, students try to use a formal mathematical model for inverse proportion, just like Student 37 did. The mathematical model follows the formal form of inverse proportion stated by Ben-Chaim et al. (2012, p. 33) that the inverse proportion consists of four variables. One of the variables is unknown. Second, students use the ratio table to make it easier to find the correct proportion for solving inverse proportion problems. For example, student 9 multiplies the amount of time it takes and the number of people doing classroom clean-up so that the product is 50 from both variables. To get the same number, Student 9 divides 50 by the number of people who will clean up, which is five people. Student 9 found that the time it took five people to clean up was 10 minutes.

\begin{tabular}{|c|c|}
\hline 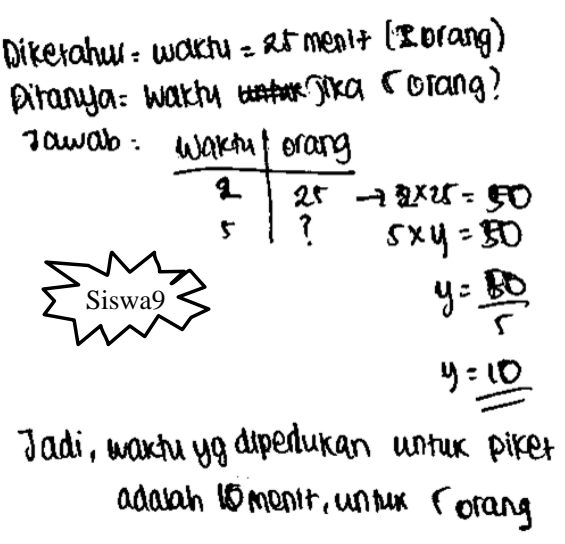 & 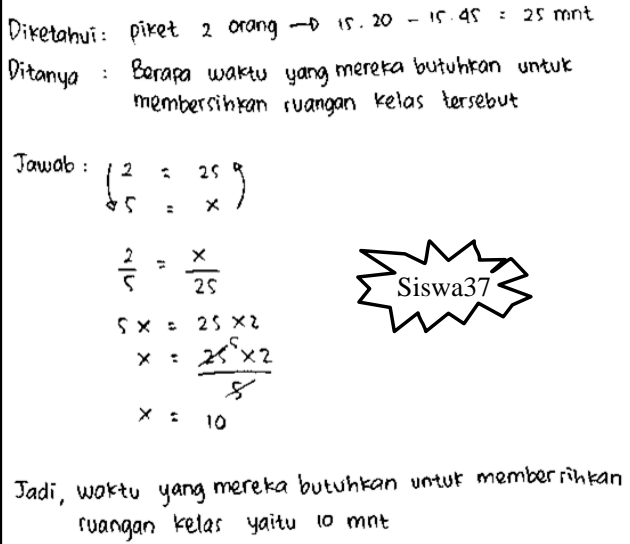 \\
\hline $\begin{array}{l}\text { Translations: } \\
\text { Student } 9 \\
\text { Given: time }=25 \text { minutes }(2 \text { people }) \\
\text { Asked: How many minutes required for } \\
\text { five people } \\
\begin{array}{r|c}\text { Answer: } \\
\text { Time } & \text { People } \\
2 & 25 \\
5 & ? \\
2 \times 25 & =50 \\
5 \times y & =50 \\
y & =\frac{50}{5} \\
& =10\end{array} \\
\text { So, the time required for classroom } \\
\text { cleanup is } 10 \text { minutes for five people. }\end{array}$ & $\begin{array}{l}\text { Student } 37 \\
\text { Given: clean-up } 2 \text { people }=15.20-15.45= \\
25 \text { minutes } \\
\text { Asked: How long will it take for } 5 \text { people to } \\
\text { clean the classroom } \\
\text { Answer: } \\
\begin{aligned} 2=25 \\
5\end{aligned}=x \\
\frac{2}{5}=\frac{x}{25} \\
\begin{aligned} 5 x & =25 \times 2 \\
x & =\frac{25 \times 2}{5} \\
x & =10\end{aligned} \\
\text { So, the time required to clean up the } \\
\text { classroom is } 10 \text { minutes. }\end{array}$ \\
\hline
\end{tabular}

Figure 2. Example of student answer to question 2

On the interview, we asked Student 37 to explain the meaning of the up and down arrows on the answer sheet, as shown in Figure 2. Student 37 intuitively knew that question 2 was about the inverse proportion, and it required an inverse proportion between the number of people who cleaned up and the time needed to finish the activity. Thus, Student 37 shows the proportional reasoning ability with the ability of students to answer questions intuitively. Ben-Chaim et al. (2012, p. 49) stated that the intuitive component refers to the student's ability to recognize a proportional relationship, either implicitly or 
explicitly. Meaning, students can well understand the proportional relationship even it is not emphasizing that the problem is a problem of proportion. Students understand that there is a proportional relationship with their intuition.

However, when Student 37 was asked the meaning of the inverse proportion, he was unable to explain it correctly. Students 37 know the different types of direct proportion questions with the inverse proportion but cannot explain the difference between them. That shows students only understand implicitly the proportional relationship contained in the problem.

Students who answered the inverse proportion's problem correctly are less than whose answered the direct proportion's problem. The aspects seen in indicator 2 are the students' answers, and their abilities in analyzing the proportional relationship asked inside questions. Even though students can correctly answer the direct proportion problem, many students can still analyze the relationship between the length of time for two people to complete the clean-up and five people to complete the clean-up. There are several types of answers given by students for indicator 2, including: (a) students cannot write down the relationship between the length of time it takes two people to complete the clean-up and five people to complete the clean-up at all. Not at all means that students do not give answers nor give answers but are not relevant at all; (b) write down the relationship between the length of time it takes for two people to complete the clean-up and five people to complete the clean-up qualitatively; (c) students answer using the concept of units; (d) students use the proportion to answer the relationship between the length of time for two people and five people to complete the classroom clean-up.

The results from question 2 indicate that most of the students still unable to complete the inverse proportion correctly. Students also have not been able to find the multiplicative relationship that exists in the problem appropriately. That shows the low of students' proportion reasoning ability for the problem of inverse proportion.

Most of the students did not understand the question of proportion problems. The example of students' answers shown in Figure 3. Students 27 did not fully understand the proportion problems. The students' proportional reasoning ability is still not good enough. It is because the proportions executed by students for the problems are still inaccurate. For example, Student 27 knows that options 1 and 2 will both get 84 packs of chocolate; it's just that the price of option 1 (the medium box) is cheaper than the price for one large box. However, Student 27 forgets that for the 1st option, Andi can buy four medium-sized boxes, and for the 2nd option, Andi can buy three large boxes so that both of them will get 84 packs of chocolate.

\begin{tabular}{|c|c|}
\hline 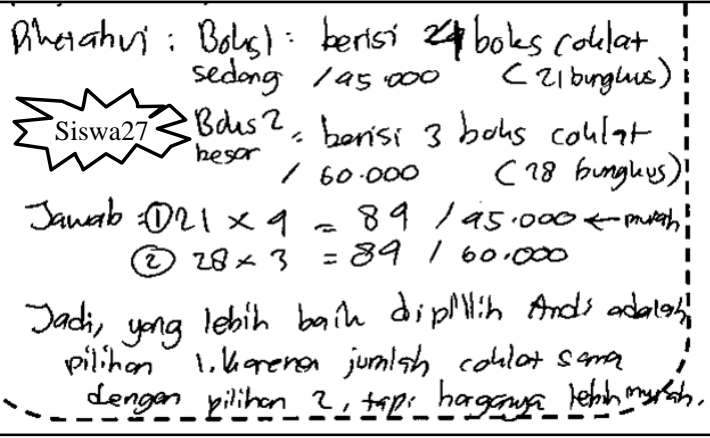 & 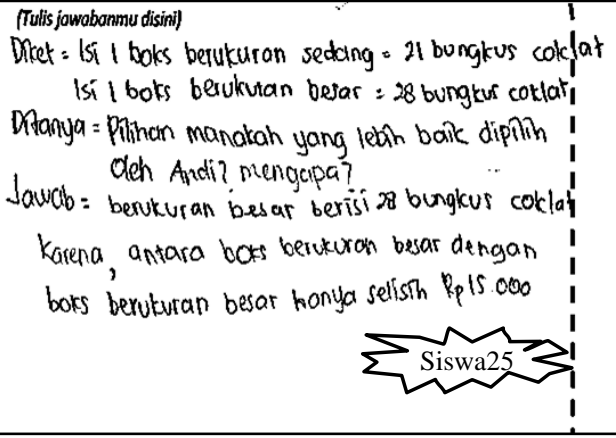 \\
\hline $\begin{array}{l}\text { Translations: } \\
\text { Student } 27 \\
\text { Given: Option one consists of } 4 \text { medium-sized boxes } \\
\text { of chocolate ( } 45,000 \text { IDR) } \rightarrow 21 \text { packs } \\
\text { Option two consist of } 3 \text { large-sized boxes of chocolate } \\
(60,000 \text { IDR) } \rightarrow 28 \text { packs } \\
\text { Answer: } \\
\text { 1) } 21 \times 4=84 / 45,000 \leftarrow \text { cheaper } \\
2) 28 \times 3=84 / 60,000 \\
\text { So, Andi better chooses option } 1 \text { because the } \\
\text { chocolate's total is still the same as option } 2 \text { with the } \\
\text { lower price. }\end{array}$ & $\begin{array}{l}\text { Student } 25 \\
\text { Given: One medium-sized box } \rightarrow 21 \text { packs of } \\
\text { chocolate } \\
\text { One large-sized box } \rightarrow 28 \text { packs of chocolate } \\
\text { Asked: Which option is better for Andi? Why? } \\
\text { Answer: } \\
\text { The large-sized box contains } 28 \text { packs of } \\
\text { chocolate and because both boxes have only } \\
15,000 \text { IDR difference }\end{array}$ \\
\hline
\end{tabular}

Figure 3. Example of student answer to question 3 
Student 25 in Figure 15 also did not understand the given proportion problems well. It shows that the students' proportional reasoning ability is not good. Student 25 made a proportion toward the price per 1 box only. One medium-sized chocolate box containing 21 packs of chocolate costs 45,000 IDR, and the cost of one large box containing 28 packs of chocolate is 60,000 IDR. Student 25 answered that it is better if they buy a large box of chocolate because it has more chocolate than in a medium box, and the price difference between the two is 15,000 IDR. Student 25 made a proportion of each content per box neglect the fact that for the first option, Andi can buy four medium-sized boxes for 180,000 IDR, and for the second option, Andi can buy three large boxes for the same amount of money, which is 180,000 IDR.

\section{Discussion}

Based on the results of the study, it was found that each student has different proportional reasoning abilities. The school category reflects the student's ability to solve proportional problems. Students from very high and high categories schools can solve the proportion problems better than students from medium and low categories schools. However, the ability of students to solve proportional problems does not ensure that students' proportional reasoning ability is also good. Students who can solve proportional problems do not necessarily fulfill all indicators of proportional reasoning ability (express, analyze, and explain answers related to a proportional relationship). Aryvaty and Saputra (2013) stated that students must involve proportional reasoning in the problem-solving process. Through the problem-solving process, students' proportional reasoning abilities can be trained.

It was still found that students were solving the inverse proportion problem using mathematical modeling for the direct proportion for each school category. It happens because students do not understand the quantity relationship in the problems. If the students do not understand the quantity relationship first, they cannot distinguish between direct proportion and inverse proportion (Nugraha et al., 2016; Raharjanti et al., 2016).

For each school category, students who had difficulty solving proportion problems were also discovered. In proportion problems, students tend to use cross multiplication in solving these problems. The constrain experienced by students are due to students' lack of understanding of the multiplicative relationships in proportions (Prayitno et al., 2019; Silvestre \& da Ponte, 2012; Vig et al., 2015).

To improve students' proportional reasoning abilities, teachers can design lessons to enhance students' multiplicative thinking skills first. Carroll (Hurst \& Hurrell, 2016, p. 7) describes several strategies that teachers can use to improve students' multiplicative thinking skills, including allowing students to work in their way in solving problems that require multiplicative thinking. Teachers can use that method to increase the students' enthusiasm in solving the given problems. In addition, teachers can also compare additive and multiplicative learning approaches.

\section{CONCLUSION}

Students' proportional reasoning ability levels generally reflect the school category. Students in very high and high category schools have moderate proportional reasoning ability. Meanwhile, students in medium and low category schools have low proportional reasoning ability. The difficulties that students experience in solving proportional reasoning problems differ based on the type of question. This study only describes students' proportional reasoning abilities based on school categories based on national mathematics test scores. As a result, there is no further discussion regarding the relationship between learning achievement and students' proportional reasoning abilities, namely how the two affect each other. However, the teacher can use this study result to plan the appropriate learning process for their students. Further research can also elaborate based on the results of this research to improve the quality of education in Indonesia in general. We suggest that future research is expected to organize an appropriate learning process based on students' proportional reasoning ability level and develop appropriate teaching materials to improve students' proportional reasoning abilities or research to determine what factors affect proportional reasoning abilities and student learning achievement.

\section{REFERENCES}

Aryvaty, A., \& Saputra, C. (2013). Pengaruh model pembelajaran berbasis masalah (PBM) terhadap kemampuan penalaran proporsional siswa sekolah menengah pertama [The effect of problem- 
based learning model on the proportional reasoning ability of junior high school students]. Jurnal Pendidikan Matematika, 4(1), 61-72. https://doi.org/http://dx.doi.org/10.36709/jpm.v4i1.2002

Azwar, S. (2015). Tes prestasi, fungsi dan pengembangan pengukuran prestasi belajar [Achievement test, function and development of learning achievement measurement]. Pustaka Pelajar.

Ben-Chaim, D., Keret, Y., \& Ilany, B. S. (2012). Ratio and proportion. Sense Publishers.

Carney, M. B., Hughes, G., Brendefur, J. L., Crawford, A., Totorica, T., \& Smith, E. (2015). Analysis of students' proportional reasoning strategies. The 37th Annual Conference of the North American Chapter of International Group for the Psychology of Mathematics Education, March 2016. https://scholarworks.boisestate.edu/cifs_facpubs/156/

Creswell, J. W., \& Plano-Clark, V. L. (2011). Choosing a mixed methods design. Designing and Conducting Mixed Method Research, 2, 53-106. https://www.sagepub.com/sites/default/files/upmbinaries/10982_Chapter_4.pdf

Dooley, K. B. (2006). An investigation of proportional thinking among high school students [Doctoral dissertation, Clemson University]. https://tigerprints.clemson.edu/all_dissertations/17/

Hilton, A., Hilton, G., Dole, S., \& Goos, M. (2016). Promoting middle school students' proportional reasoning skills through an ongoing professional development programme for teachers. Educational Studies in Mathematics, 92(2), 193-219. https://doi.org/10.1007/s10649-016-9694-7

Howe, C., Nunes, T., \& Bryant, P. (2011). Rational number and proportional reasoning: Using intensive quantities to promote achievement in mathematics and science. International Journal of Science and Mathematics Education. 9(2), 391-417. https://doi.org/10.1007/s10763-010-9249-9

Hurst, C., \& Hurrell, D. (2016). Investigating children's multiplicative thinking: Implications for teaching. European Journal of STEM Education, 1(3), 1-11. https://doi.org/10.20897/lectito.201656

Lamon, S. J. (1993). Ratio and proportion: Connecting content and children's thinking. Journal for Research in Mathematics Education, 24(1), 41-61. https://doi.org/10.2307/749385

Lamon, S. J. (2012). Teaching fractions and ratios for understanding: Ratio and proportion (3rd ed.). Routledge.

Langrall, C. W., \& Swafford, J. (2000). Three balloons for two dollars: Developing proportional reasoning. Mathematics Teaching in The Middle School, 6(4), 254-261. https://doi.org/10.5951/MTMS.6.4.0254

Lobato, J., \& Ellis, A. B. (2010). Developing essential understandings of ratios, proportions, and proportional reasoning for teaching mathematics: Grades 6-8. National Council of Teachers of Mathematics.

Mcintosh, M. B. (2013). Developing proportional reasoning in middle school students [Master's thesis, The University of Utah]. https://csme.utah.edu/wp-content/uploads/2013/06/MarcieMcIntosh.pdf

Ministry of Education and Culture. (2016). Regulation of Minister of Education and Culture Republic of Indonesia number 24 of 2016 appendix 14 concerning elementary school curriculum.

Modestou, M., \& Gagatsis, A. (2010). Cognitive and metacognitive aspects of proportional reasoning. Mathematical Thinking and Learning, 12(1),36-53. https://doi.org/10.1080/10986060903465822

NCTM. (2000). Principles and standards for school mathematics. Author.

Nugraha, Y., Sujadi, I., \& Pangadi, P. (2016). Penalaran proporsional siswa kelas VII [Grade VII students' proportional reasoning]. Beta: Jurnal Tadris Matematika, 9(1), 34-47. https://doi.org/10.20414/betajtm.v9i1.2

Prayitno, A., Rossa, A., \& Widayanti, F. D. (2019). Level penalaran proporsional siswa dalam memecahkan missing value problem [The level of students' proportional reasoning in solving the missing value problem]. Jurnal Riset Pendidikan Matematika, 6(2), 177-187.

https://doi.org/10.21831/jrpm.v6i2.19728 
Raharjanti, M., Nusantara, T., \& Mulyati, S. (2016). Kesalahan siswa dalam menyelesaikan permasalahan perbandingan senilai dan berbalik nilai [Student errors in solving the problem of direct and inverse proportion]. Konferensi Nasional Penelitian Matematika dan Pembelajarannya (KNPMP I). https://publikasiilmiah.ums.ac.id/handle/11617/6971

Silvestre, A. I., \& da Ponte, J. P. (2012). Missing value and comparison problems: What pupils know before the teaching of proportion. PNA, 6(3), 73-83. https://doi.org/10.30827/pna.v6i3.6142

Steinthorsdottir, O. B. (2005). Girls journey towards proportional reasoning. Proceedings of the 29th Conference of the International Group for the Psychology of Mathematics Education, 4, 225232.

https://www.emis.de/proceedings/PME29/PME29RRPapers/PME29Vol4Steinthorsdottir.pdf

Sumarto, S. N. (2013). Design research on mathematics education: Ratio table in developing the students' proportional reasoning [Masters' thesis, Universitas Sriwijaya, and Utrecht University]. http://www.fisme.science.uu.nl/en/impome/theses_group_2012/thesis_Sylvana.pdf

Tjoe, H., \& Torre, J. De. (2013). Designing cognitively-based proportional reasoning problems as an application of modern psychological measurement models. Journal of Mathematics Education, 6(2), 17-26. http://personal.psu.edu/hht1/Tjoe_2013_JME.pdf

Van de Walle, J. A. (2007). Elementary and middle school mathematics: Teaching developmentally (6th ed.). Pearson Education.

Vig, R., Star, J. R., Dupuis, D. N., Lein, A. E., \& Jitendra, A. K. (2015). Exploring the impact of knowledge of multiple strategies on students' learning about proportions. In J. Middleton, J. Cai, S. Hwang (Eds.), Large-scale studies in mathematics education (pp. 61-73). Springer. https://doi.org/10.1007/978-3-319-07716-1_4 